129

A CONQUISTA DA

OPILIAO PUंBLICA COMO O DISCURSO MANIPULA AS ESCOLHAS POLITICAS

\section{PATRICK CHARAUDEAU}

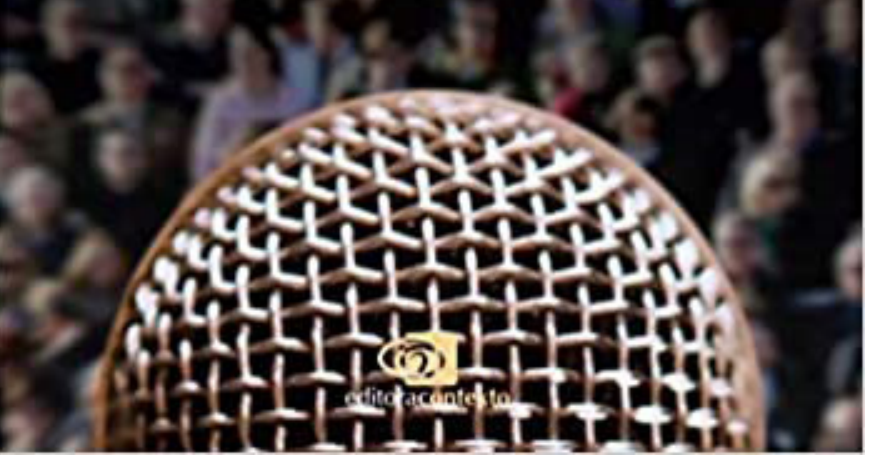

Patrick Charaudeau.

A conquista da opinião públicacomo o discurso manipula as escolhas políticas

Contexto

São Paulo, 2020.

192 páginas

Livre Docente e Doutor em Comunicação e Cultura pela Universidade de São Paulo (USP).

Professor Associado da Escola de Comunicações e Artes da USP (ECA-USP).

Professor Titular da Universidade Metodista de São Paulo.

- E-mail: lafarias@usp.br 


\section{Parece teorema, mas é só distração}

\section{Seems as a theorem, but it is simply distraction}

\section{Parece un teorema, pero solo es una distracción}

S omos gestos, palavras, ações, silêncios. Somos discurso em cada movimento que se destina à conquista de atenções, de decisões. A conquista da opinião alheia, em especial da opinião pública, é sonho de consumo que leva ao poder concreto e simbólico, à conquista de mercados, seguidores, eleitores. 0 uso de estratégias sutis de construções discursivas permite esse tipo de conquista e de manutenção de status. Portanto, pode efetivamente representar poder.

Os diversos tipos de organização - privadas, públicas, que não visem ao lucro - são impactadas diretamente pelos movimentos opinativos existentes na esfera pública. Governo, os assim chamados mercados e empresas são todos impactados por discursos, por pautas, pelas impressões decorrentes de fatos. Em tempos de desinformação galopante, a luta pela conquista da atenção e da opinião dos públicos se torna mais explícita, vista em redes sociais digitais e nas mídias tradicionais. Termos como fake news, CPI, bots e ciborgues crescem e passam a fazer parte recorrente de notícias e dos diálogos, mesmo entre os cidadãos médios.

Democracia, totalitarismo, crescimento econômico, crises, imagem, consumo e diversos outros pontos são parte das construções discursivas e de processos manipulativos de diversas fontes. Note-se que em tempos digitais cresceu o nível de "profissionalização" das construções discursivas. Experiências mundo afora demonstram que o populismo digital ganha força movido por verdadeiros protocolos de gestão de comunicação, buscando atingir públicos previamente estudados e renovando discursos adaptados a demandas sensíveis à opinião pública. É claro que movimentações políticas sempre o fizeram, em algum nível e em alguma medida, mas nunca com tanta agilidade e massificação, nem de maneira tão instantânea.

A obra A conquista da opinião pública, produzida pelo linguista francês Patrick Charaudeau, discute o que existe por trás do poder político e como se busca a conquista dos públicos e da adesão a projetos políticos. É claro que falar de busca de apoio e de aceitação está vinculado a cenários democráticos. Ambientes nos quais a democracia é travestida, disfarçada, colapsada também podem receber construções discursivas que gerem um maior nível de aceitação, até de conformismo.

Charaudeau trata do uso da palavra e do discurso utilizados como elementos para construção do caminho necessário para alcançar o poder. Os diversos mecanismos construídos para geração de discursos altamente convincentes servem para levar pessoas ao poder, transformando-as em porta-vozes de cidadãos, seduzindo e persuadindo grupos, multidões e massas em favor de projetos de poder.

Trata-se de máquinas construídas de forma silenciosa, velada, muitas vezes obscura, mas, ao mesmo tempo, do conhecimento de todos. Não é exclusividade de nenhuma ideologia, de nenhum campo de pensamento, seja ele mais progressista ou retrógrado, libertador ou conservador, de direita ou esquerda. As construções discursivas visando ao controle da opinião 
pública - mais do que controle, conquista! - estão espalhadas por todo o mundo, e talvez sendo melhor utilizadas por alguns grupos políticos do que outros. Mas não com exclusividade, vale destacar.

0 autor compõe seu livro por três capítulos e, desde o início, de forma bastante didática e provocativa. Conceitua os diversos termos e formas de pensamento sobre identidade e opinião, demonstrando que se referem à opinião pública elementos de geração de identificação, estes trabalhados em processos político-discursivos. Segue tocando em um ponto sempre muito polêmico: afinal, existe manipulação ou apenas influência? Parece que, para ele, essa é uma questão resolvida, pois não apenas trabalha o tema como o destrincha e apresenta um rol de elementos que fazem parte do roteiro da conquista da opinião pública, tocando, inclusive, em um ponto de forte apelo contemporâneo: o populismo.

Charaudeau trata de alguns dos grandes problemas enfrentados pelos cidadãos atualmente. Pode-se ver, a partir de seu texto, as ameaças ao jogo democrático, a construção de personas heroificadas a partir de discursos cuidadosamente elaborados, apelando-se à construção de figuras quase etéreas. A obra trata de um aspecto vital para o nosso tempo: a democracia.

Fortes ondas de populismo em diversas partes do mundo - encorpadas por movimentos eugenistas, supremacistas, racistas e de outros inaceitáveis tons de intolerância - são embaladas por discursos manipuladores que trazem risco à liberdade, aumentados e estimulados por tecnologias que constroem realidades paralelas. Esse cenário alimenta e é alimentado por desinformação, em especial a construída por verdadeiras indústrias e exércitos focados em deslocamento dos fatos.

A obra de Patrick Charaudeau nos alerta para os movimentos silenciosos que conspiram para levar ao poder muitos discursos que travestem a realidade e criam um mundo no qual o fato pode perder espaço para as versões e o desejo de acreditar sem crítica, sem debate.

Texto recebido em 30.04.2021 e aprovado em 18.05.2021 